\title{
Two Caddo Sites in the Attoyac Bayou Basin in the East Texas Pineywoods, San Augustine County, Texas
}

Timothy K. Perttula Heritage Research Center, Stephen F. Austin State University

Follow this and additional works at: https://scholarworks.sfasu.edu/ita

Part of the American Material Culture Commons, Archaeological Anthropology Commons, Environmental Studies Commons, Other American Studies Commons, Other Arts and Humanities Commons, Other History of Art, Architecture, and Archaeology Commons, and the United States History Commons

Tell us how this article helped you.

This Article is brought to you for free and open access by the Center for Regional Heritage Research at SFA ScholarWorks. It has been accepted for inclusion in Index of Texas Archaeology: Open Access Gray Literature from the Lone Star State by an authorized editor of SFA ScholarWorks. For more information, please contact cdsscholarworks@sfasu.edu. 
Two Caddo Sites in the Attoyac Bayou Basin in the East Texas Pineywoods, San Augustine County, Texas

\section{Creative Commons License}

\section{(c) (i) (8)}

This work is licensed under a Creative Commons Attribution-NonCommercial 4.0 International License 


\title{
Two Caddo Sites in the Attoyac Bayou Basin in the East Texas Pineywoods, San Augustine County, Texas
}

\author{
Timothy K. Perttula
}

\section{INTRODUCTION}

This article concerns two ancestral Caddo sites in San Augustine County on tributaries to Attoyac Bayou in the East Texas Pineywoods (Figure 1): 41SA7 and 41SA13. Both sites were recorded in April and May 1940 by G. E. Arnold of The University of Texas in Austin as part of a larger archaeological survey of East Texas (Im 1975).

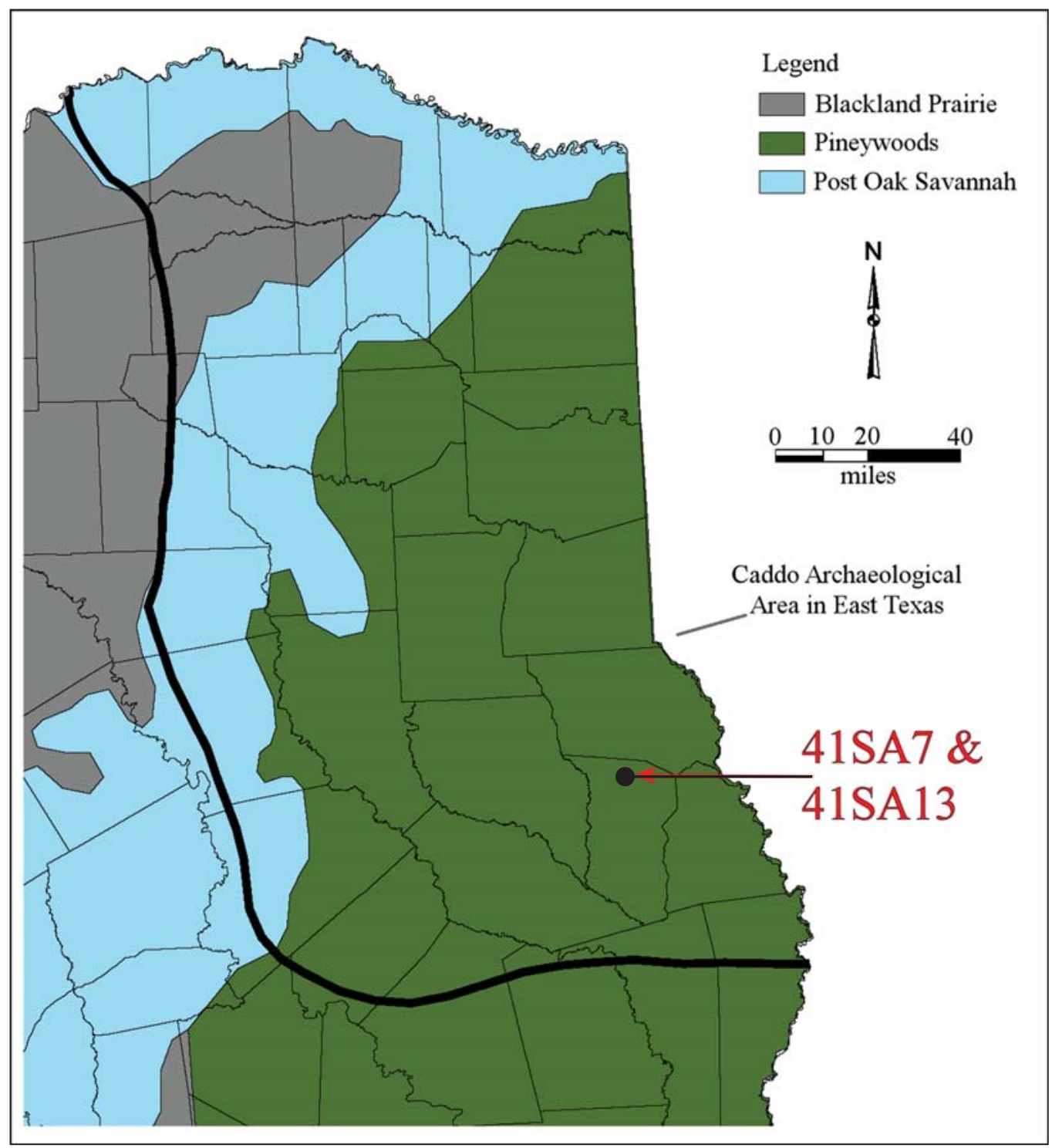

Figure 1. The location of 41SA7 and 41SA13 in East Texas. 


\section{SETTING OF THE TWO SITES}

Site 41SA7 is located on a natural sandy knoll about 1.5 acres in size in the floodplain of Big Arenosa and Colder creeks. In addition to numerous Caddo ceramic sherds on the surface, Arnold (1940) noted that there were "extensive quantities of burned and unburned animal bone" on the surface of the site. This suggests that there is or was a well-preserved midden deposit at 41SA7.

41SA13 is on a 2 acre sandy ridge on the north side of Big Iron Ore Creek, which flows into Arenosa Creek, a tributary to Attoyac Bayou. When Arnold (1940) recorded the site there were numerous Caddo ceramic sherds on the surface, and he noted that when a railroad track had been excavated through the ridge several years earlier, an unknown number of Caddo burials had been exposed at about $1.2 \mathrm{~m}$ in depth. These burials contained an unknown number of ceramic vessels and arrow points, as well as preserved skeletal remains. According to the landowner, one of the burials had two hematite ear spools (see below).

\section{CERAMIC ASSEMBLAGES}

\section{SA7}

The sample of ceramic sherds from 41SA7 comprises 131 plain ware sherds, 177 sherds from utility ware vessels, and only 20 sherds from fine ware vessels (Table 1). The plain to decorated sherd ratio is a low 0.66 , and approximately 60 percent of the sherds in the assemblage have decorations. The ratio of utility ware sherds to fine ware sherds is 8.9:1.

Table 1. Ceramic assemblage from 41SA7.

\begin{tabular}{llll}
\hline Ware & Grog & Bone & N \\
\hline Plain & 59 & 72 & 131 \\
Utility & 63 & 113 & $177^{*}$ \\
Fine & 8 & 12 & 20 \\
\hline Totals & 130 & 197 & $328^{*}$ \\
\hline
\end{tabular}

*includes one sherd with visible temper and a sandy paste

The ceramic sherd assemblage is dominated by bone-tempered vessels in all three wares. A total of 60 percent of the sherds are from bone-tempered vessels (see Table 1).

There is a very high proportion of brushed sherds in the 41SA7 utility wares: 81 percent of the utility ware sherds have horizontal and vertical brushing marks on the rim and opposed, overlapping, and vertical brushing marks on the body of jars (Table 2). Perhaps these are from Broaddus Brushed vessels (Jelks 1965). Another 3.4 percent of the utility ware sherds have brushed-appliqued, brushed-incised, and brushedpunctated decorative elements; these sherds are likely from Pease Brushed-Incised vessels.

About 8 percent of the sherds from utility ware vessels have incised decorative elements (see Table 2), including a Pease Brushed-Incised jar with vertical panels filled with diagonal opposed incised lines (Figure 2a). The few incised-punctated rim and body sherds (1.7 percent of the utility ware sherds) have curvilinear incised zones with tool punctates and a diagonal row of tool punctates (Figure 2d); diagonal incised lines and a tool punctated row under the lip (Figure 2c); and a body sherd with a straight line and adjacent tool punctated zones (Figure 2b). 
Table 2. Decorative elements in the utility ware sherds from 41SA7.

\begin{tabular}{llllll}
\hline Decorative method/ & \multicolumn{2}{c}{ Grog } & \multicolumn{2}{c}{ Bone } \\
Decorative element & Rim & Bim & Body & $\mathrm{N}$ \\
\hline
\end{tabular}

\section{Brushed}

diagonal brushing

horizontal brushing

opposed brushing

overlapping brushed

parallel brushing

vertical brushing

\section{Brushed-Appliqued}

parallel brushed-straight appliqued fillet

\section{Brushed-Incised}

parallel brushed-incised lines

\section{Brushed-Punctated}

parallel brushed-tool punctated

row through brushing

\section{Incised}

diagonal opposed lines

horizontal and curvilinear lines

parallel lines

straight line

vertical lines and diagonal

opposed panels

\section{Incised-Punctated}

curvilinear incised zones with tool punctates and a diagonal row of tool punctates diagonal incised (R-L) and tool punctated row under lip straight line and adjacent tool punctated zones

\section{Lip Notched}

\section{Pinched}

parallel pinched ridges

\section{Punctated}

fingernail punctated rows

tool punctated rows

$\begin{array}{lr}- & - \\ 1 & - \\ - & 2 \\ - & - \\ - & 41 \\ - & -\end{array}$

$1-1$

$\begin{array}{lll}6 & - & 7\end{array}$

125

$\begin{array}{lll}1 & 4\end{array}$

$-\quad 85$
$-\quad 126$

1

126

1

1

$\begin{array}{llllll}- & 1 & - & - & 1\end{array}$

$\begin{array}{lllll}- & - & - & 1 & 1\end{array}$

$\begin{array}{lllll}- & 4 & - & 4 & 9\end{array}$

$\begin{array}{lllll}- & 1 & - & 1 & 2\end{array}$

$-$

2

$-$

1

1

1

$-$

1

5


Table 2. Decorative elements in the utility ware sherds from 41SA7, cont.

\begin{tabular}{lccccc}
\hline $\begin{array}{l}\text { Decorative method/ } \\
\text { Decorative element }\end{array}$ & Rim & Body & Rim & Body & N \\
\hline Ridged & & & & & \\
$\begin{array}{l}\text { parallel ridges } \\
\text { parallel ridges with parallel } \\
\text { brushing between ridges }\end{array}$ & - & 2 & - & - & 2 \\
\hline Totals & - & - & - & 1 & 1 \\
\hline
\end{tabular}

*includes one parallel incised body sherd with no apparent temper, only a sandy paste

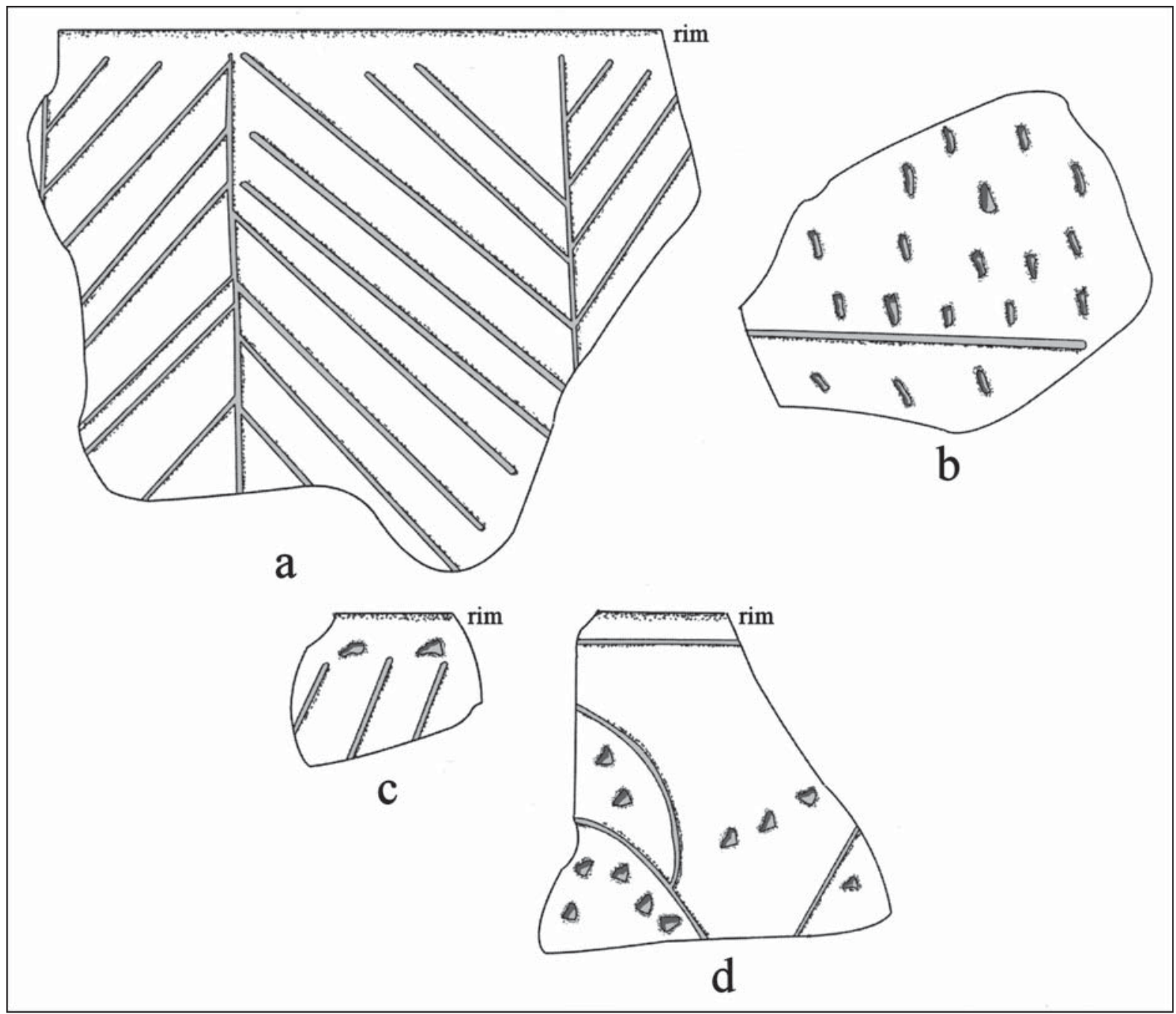

Figure 2. Selected decorative elements on utility ware sherds from 41SA7: a, incised rim; b, incised-punctated body; c-d, incised-punctated rims.

The utility ware assemblage also has one bone-tempered rim with lip notching, a Killough Pinched body sherd, and body sherds with either fingernail or tool punctated rows. The punctated sherds comprise 2.8 percent of the 41SA7 utility ware sherds (see Table 2 ). 
At 41SA7, ridged sherds comprise 1.7 percent of the utility ware sherds (see Table 2). Ridged utility ware sherds (i.e., from Belcher Ridged jars, see Suhm and Jelks 1962:11 and Plate 6) are common (in proportions greater than 4.0 percent of decorated sherd assemblages) only in post-A.D. 1500 East Texas and western Louisiana Caddo communities in one locale along the Sabine River in the Toledo Bend Reservoir area (Perttula 2015:Figure 6), but are present in Late Caddo sites in the Angelina and Attoyac stream basins.

Belcher Ridged is one of the principal utility wares in Belcher phase sites on the Red River in northwestern Louisiana and southwestern Arkansas. This area is more than ca. $70 \mathrm{~km}$ north of the Sabine River sites where ridged pottery is relatively common, and farther than that from 41SA7. The Belcher Ridged sherds at 41SA7 include both var. Belcher $(\mathrm{n}=2)$ and var. Byram Ferry $(\mathrm{n}=1)($ see Girard 2007:15). The var. Byram Ferry appears to be a 15th century variety of the type, while var. Belcher of Belcher Ridged can be dated from ca. A.D. 1500-1700.

The fine ware sherds from 41SA7 are stylistically diverse (Table 3). Two sherds are from Patton Engraved vessels (Figure 3g-h), with horizontal engraved lines on the rim of carinated bowls that have excised pendant triangles either pointing towards the rim or the vessel carination. The occurrence of Patton Engraved vessel sherds in the assemblage suggests that 41SA7 was at least occupied after ca. A.D. 1650, likely during historic times (cf. Fields 1995; Story 1982, 1995). Another rim sherd has a horizontal engraved line and hatched pendant triangles (Figure 3d).

Table 3. Decorative elements in the fine ware sherds from $41 S A 7$.

\begin{tabular}{|c|c|c|c|c|c|}
\hline \multirow{2}{*}{$\begin{array}{l}\text { Decorative method/ } \\
\text { Decorative element }\end{array}$} & \multicolumn{2}{|c|}{ Grog } & \multicolumn{2}{|c|}{ Bone } & \multirow[b]{2}{*}{$\mathrm{N}$} \\
\hline & Rim & Body & Rim & Body & \\
\hline \multicolumn{6}{|l|}{ Engraved } \\
\hline concentric semi-circles & - & - & - & 1 & 1 \\
\hline cross-hatched zone & - & - & - & 1 & 1 \\
\hline $\begin{array}{l}\text { cross-hatched zone and } \\
\text { parallel lines }\end{array}$ & - & - & - & 1 & 1 \\
\hline $\begin{array}{l}\text { curvilinear hatched and cross- } \\
\text { hatched zones and negative ovals }\end{array}$ & - & 1 & - & - & 1 \\
\hline curvilinear lines & - & 1 & - & - & 1 \\
\hline diagonal lines (L-R) & - & - & 1 & - & 1 \\
\hline diagonal lines (R-L) & - & - & - & 1 & 1 \\
\hline $\begin{array}{l}\text { diagonal lines }(\mathrm{R}-\mathrm{L}) \text { on rim and } \\
\text { horizontal brushed body }\end{array}$ & - & - & - & 1 & 1 \\
\hline diagonal opposed lines & - & - & 1 & - & 1 \\
\hline hatched zone & - & - & - & 1 & 1 \\
\hline hatched triangle & - & 1 & - & - & 1 \\
\hline $\begin{array}{l}\text { horizontal lines and excised } \\
\text { pendant triangles }\end{array}$ & - & 1 & 1 & - & 2 \\
\hline $\begin{array}{l}\text { horizontal line and hatched } \\
\text { pendant triangles }\end{array}$ & 1 & - & - & - & 1 \\
\hline horizontal and vertical lines & 1 & - & - & - & 1 \\
\hline
\end{tabular}


Table 3. Decorative elements in the fine ware sherds from 41SA7, cont.

\begin{tabular}{|c|c|c|c|c|c|}
\hline \multirow{2}{*}{$\begin{array}{l}\text { Decorative method/ } \\
\text { Decorative element }\end{array}$} & \multicolumn{2}{|c|}{ Grog } & \multicolumn{2}{|c|}{ Bone } & \multirow[b]{2}{*}{$\mathrm{N}$} \\
\hline & $\operatorname{Rim}$ & Body & Rim & Body & \\
\hline opposed lines & - & 1 & - & - & 1 \\
\hline $\begin{array}{l}\text { slanted scroll and vertical lines } \\
\text { in scroll fill zone }\end{array}$ & - & - & 2 & - & 2 \\
\hline $\begin{array}{l}\text { slanted scroll, cross-hatched } \\
\text { zones and excised triangle }\end{array}$ & - & 1 & - & - & 1 \\
\hline $\begin{array}{l}\text { scroll fill zone with vertical } \\
\text { and diagonal lines }\end{array}$ & - & - & - & 1 & 1 \\
\hline Totals & 2 & 6 & 5 & 7 & 20 \\
\hline
\end{tabular}

$\mathrm{L}-\mathrm{R}=$ left to right; lines begin at the top of the rim at the left and end at the bottom of the rim at the right $\mathrm{R}-\mathrm{L}=$ right to left; lines begin at the top of the rim at the right and end at the bottom of the rim at the left

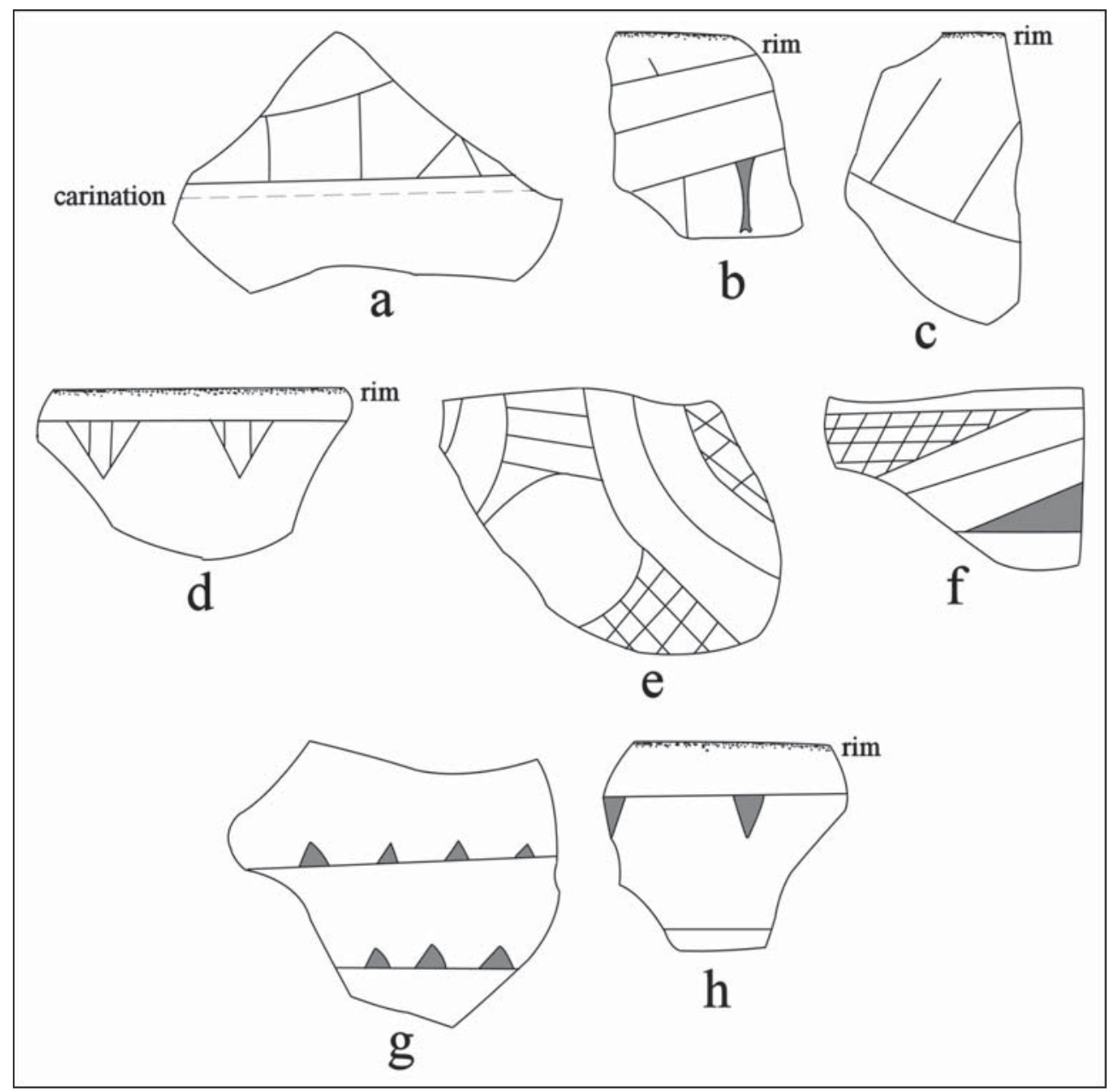

Figure 3. Selected decorative elements on fine ware sherds from 41SA7: b-d, h, rim sherd; a, e-g, body sherds. 
One body sherd from a grog-tempered vessel has hatched and cross-hatched curvilinear zones and a negative oval (see Figure 3e), and may be from a Hodges Engraved carinated bowl. Another body sherd has a slanted scroll motif with an upper cross-hatched engraved zone and a lower excised zone (see Figure 3f). As a group, the most common decorative elements in the engraved sherds from 41SA7 are rim and body sherds from carinated bowls that have slanted scroll elements (see Figure 3a-c and Table 3).

Overall, the very high proportions of sherds from brushed utility ware vessels, as well as Belcher Ridged sherds, and Patton Engraved and Hodges Engraved fine ware sherds suggests the Caddo occupation at 41SA7 occurred well after A.D. 1500. Although no European trade goods have been found at the site, it is likely that 41SA7 was occupied as late as the mid- to late-17th century by a southern Caddo group.

\section{SA13}

The sample of ceramic sherds $(\mathrm{n}=112)$ from $41 \mathrm{SA} 13$ includes 66 plain ware sherds, 36 sherds from utility ware vessels, and only 10 sherds from fine ware vessels (Table 4). The plain to decorated sherd ratio is 1.43 , and approximately 40 percent of the sherds in the assemblage have decorations. The ratio of utility ware sherds to fine ware sherds is $3.6: 1$.

Table 4. Ceramic assemblage from 41SA13.

\begin{tabular}{lccc}
\hline Ware & Grog & Bone & N \\
\hline Plain & 45 & 21 & 66 \\
Utility & 32 & 4 & 36 \\
Fine & 7 & 3 & 10 \\
\hline Totals & 84 & 28 & 112 \\
\hline
\end{tabular}

Unlike the ceramic sherd assemblage from 41SA7, the ceramic sherd assemblage from 41SA13 is dominated by grog-tempered vessels in all three wares, particularly the utility wares. A total of 75 percent of the sherds from 41SA13 are from grog-tempered vessels (see Table 4). By contrast, only 40 percent of the sherds from 41SA7 are from grog-tempered vessels.

The utility ware sherds from 41SA13 include brushed ( 33 percent), brushed-incised ( 2.8 percent), punctated (30.6 percent), incised ( 25 percent), incised-punctated (5.6 percent), and ridged ( 2.8 percent (Table 5). Sherds from brushed vessels, again, likely from Broaddus Brushed vessels, do not dominate the utility ware assemblage as compared to the 41SA7 assemblage, where they account for 81 percent of all the utility ware sherd assemblage (see Table 2). This difference likely has temporal implications, with the Caddo occupation at $41 \mathrm{~S} 13$ dating before that of the post-A.D. 1500 occupation at $41 \mathrm{SA} 7$.

Incised sherds have basic straight line and geometric elements: diagonal opposed lines (Figure 4a) as well as horizontal and vertical lines on a grog-tempered rim sherd (Figure $4 b$ ). Both incised-punctated body sherds have sets of parallel lines adjacent to a zone with rows of cane punctations (Figure 4c).

Body sherds from 41SA13 have three different kinds of punctated elements: circular-shaped, fingernail, and tool (see Table 5). These punctations occur in rows, likely on the rim as well as the body of utility ware jars.

Ridged sherds comprise 2.8 percent of the utility wares and 2.2 percent of all the decorated sherds from 41SA13. The one sherd is from a 15th century Belcher Ridged, var. Byram Ferry vessel. 
Table 5. Decorative elements in the utility ware sherds from 41SA13.

\begin{tabular}{|c|c|c|c|c|c|}
\hline \multirow{2}{*}{$\begin{array}{l}\text { Decorative method/ } \\
\text { Decorative element }\end{array}$} & \multicolumn{2}{|c|}{ Grog } & \multicolumn{2}{|c|}{ Bone } & \multirow[b]{2}{*}{$\mathrm{N}$} \\
\hline & Rim & Body & Rim & Body & \\
\hline \multicolumn{6}{|l|}{ Brushed } \\
\hline $\begin{array}{l}\text { horizontal brushed (lower rim) } \\
\text { and vertical brushed (body) }\end{array}$ & - & 1 & - & - & 1 \\
\hline parallel brushed & - & 9 & - & 2 & 11 \\
\hline \multicolumn{6}{|l|}{ Brushed-Incised } \\
\hline parallel brushed-incised lines & - & 1 & - & - & 1 \\
\hline \multicolumn{6}{|l|}{ Incised } \\
\hline horizontal lines & 2 & - & - & - & 2 \\
\hline horizontal and vertical lines & 1 & - & - & - & 1 \\
\hline diagonal opposed lines & - & 1 & - & - & 1 \\
\hline parallel lines & - & 4 & - & - & 4 \\
\hline straight line & - & 1 & - & - & 1 \\
\hline \multicolumn{6}{|l|}{ Incised-Punctated } \\
\hline $\begin{array}{l}\text { parallel lines and zone of cane } \\
\text { punctates }\end{array}$ & - & 2 & - & - & 2 \\
\hline \multicolumn{6}{|l|}{ Punctated } \\
\hline circular punctated rows & - & 1 & - & 1 & 2 \\
\hline fingernail punctated rows & - & 2 & - & - & 2 \\
\hline tool punctated rows & - & 3 & - & - & 3 \\
\hline tool punctated, single punctate & - & 4 & - & - & 4 \\
\hline $\begin{array}{l}\text { Ridged } \\
\text { parallel ridges with parallel } \\
\text { brushing between ridges }\end{array}$ & - & - & - & 1 & 1 \\
\hline Totals & 3 & 29 & - & 4 & 36 \\
\hline
\end{tabular}

Only 22 percent of the decorated sherds from 41SA13 are from fine ware vessels (Table 6). The one rim sherd from a bone-tempered carinated bowl has a set of diagonal engraved lines. The other carinated bowl sherds have horizontal and parallel lines, as well as concentric semi-circles with an excised inner semi-circle (Figure 5a).

Twenty percent of the engraved sherds from 41SA13 are from grog-tempered fine ware bottles. One has curvilinear lines, and the other has slanted scroll lines (including several very closely-spaced engraved lines) and an upper scroll fill zone with a triangle element at one end filled with curvilinear lines (Figure 5b). 


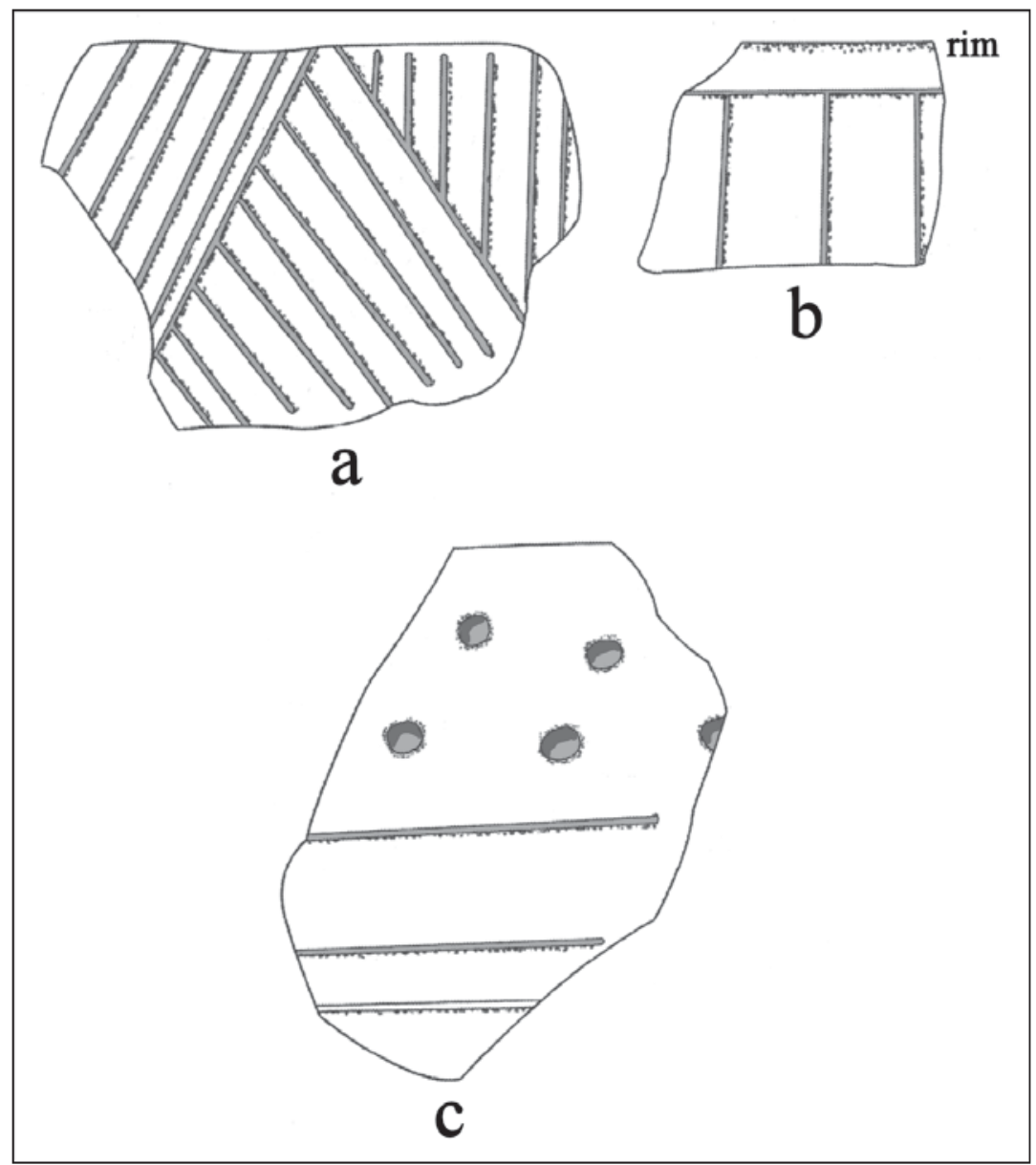

Figure 4. Selected decorative elements on utility ware sherds from 41SA13: a, incised body; b, incised rim; c, incised-punctated body.

Table 6. Decorative elements in the fine ware sherds from 41SA13.

\begin{tabular}{|c|c|c|c|c|c|}
\hline \multirow{2}{*}{$\begin{array}{l}\text { Decorative method/ } \\
\text { Decorative element }\end{array}$} & \multicolumn{2}{|c|}{ Grog } & \multicolumn{2}{|c|}{ Bone } & \multirow[b]{2}{*}{$\mathrm{N}$} \\
\hline & Rim & Body & Rim & Body & \\
\hline \multicolumn{6}{|l|}{ Engraved } \\
\hline $\begin{array}{l}\text { concentric semi-circles and } \\
\text { excised inner semi-circle }\end{array}$ & - & 1 & - & - & 1 \\
\hline curvilinear lines & - & 1 & - & - & 1 \\
\hline diagonal lines (R-L) & - & - & 1 & - & 1 \\
\hline horizontal line & - & - & - & 1 & 1 \\
\hline parallel lines & - & 4 & - & 1 & 5 \\
\hline $\begin{array}{l}\text { slanted scroll lines and } \\
\text { curvilinear lines in scroll } \\
\text { fill zone }\end{array}$ & - & 1 & - & - & 1 \\
\hline Totals & - & 7 & 1 & 2 & 10 \\
\hline
\end{tabular}

$\mathrm{R}-\mathrm{L}=$ right to left; lines begin at the top of the rim at the right and end at the bottom of the rim at the left 


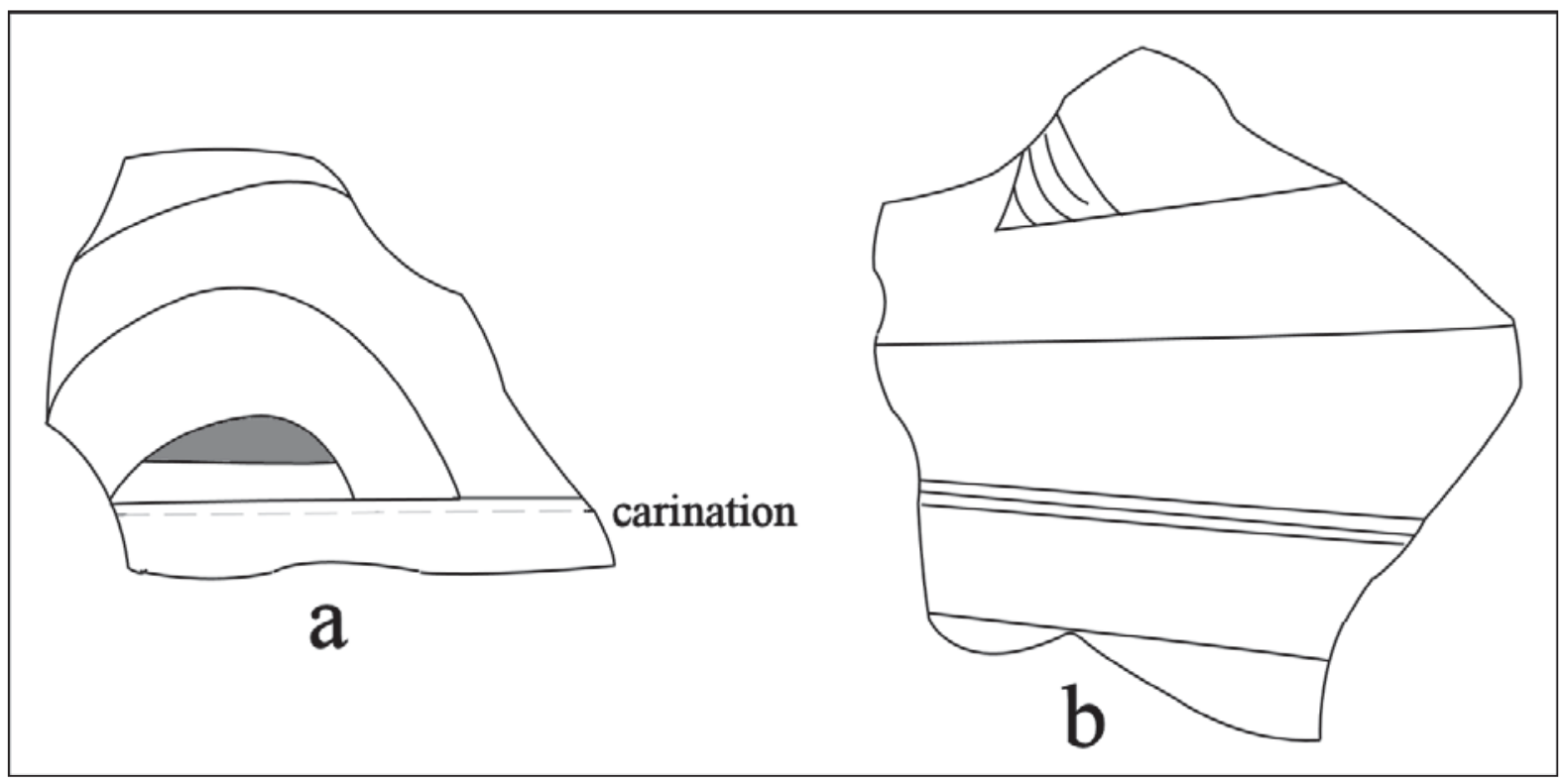

Figure 5. Selected decorative elements on fine ware sherds from 41SA13: a, carinated bowl; b, bottle sherd.

\section{CERAMIC EAR SPOOL FROM 41SA13}

The two circular hematite ear spools (Figure 6a-a') from 41SA13 had apparently been found together, one atop the other, and the area between the ear spools contained remnants of corroded copper (Arnold 1940), suggesting that the ear spools had been copper-plated. The ear spools have a central concave area on their outer surface, as well as a centrally-placed drilled hole for attaching the spools (Figure 6a). The sides of the ear spools also have concave ridges that run from one end of the spool to the other. The back side of the ear spools are flat.

In form, the ear spools from $41 \mathrm{SA} 13$ are very similar to clay ear spools from the late $15^{\text {th }}$ to early $16^{\text {th }}$ century A.D. Morse Mound site (41SY27) (Middlebrook 2014:Figure 15a-d). These ear spools, however, do not have central drilled holes that extended through the ear spools like those from 41SA13.

\section{CHIPPED STONE TOOL}

A single Bassett point was collected by Arnold from 41SA7. The point is made from a local brown chert, and is unifacially flaked; it is $18.6 \mathrm{~mm}$ in length, $12.0 \mathrm{~mm}$ in width, $3.0 \mathrm{~mm}$ in thickness, and has a stem width of $1.6 \mathrm{~mm}$.

\section{SUMMARY AND CONCLUSIONS}

Sites 41SA7 and 41SA13 are ancestral Caddo settlements on tributaries to Attoyac Bayou, in the Angelina River basin in the East Texas Pineywoods. Both sites were recorded by G. E. Arnold in 1940, and he secured collections of Caddo artifacts from both sites (primarily ceramic sherds); he also reported that Caddo burials had been encountered at 41SA13 when a railroad line was cut through the site.

Site 41SA7, with its very high proportion of brushed utility ware sherds, Belcher Ridged, var. Belcher sherds, and Patton Engraved and Hodges Engraved sherds, was apparently occupied well after ca. A.D. 1500, probably in the mid- to late-17th century. $41 \mathrm{SA} 13$, on the other hand, was most likely occupied before A.D. 1500 , based on a lower proportion of brushed sherds in the utility ware assemblage and a 15th century A.D. 


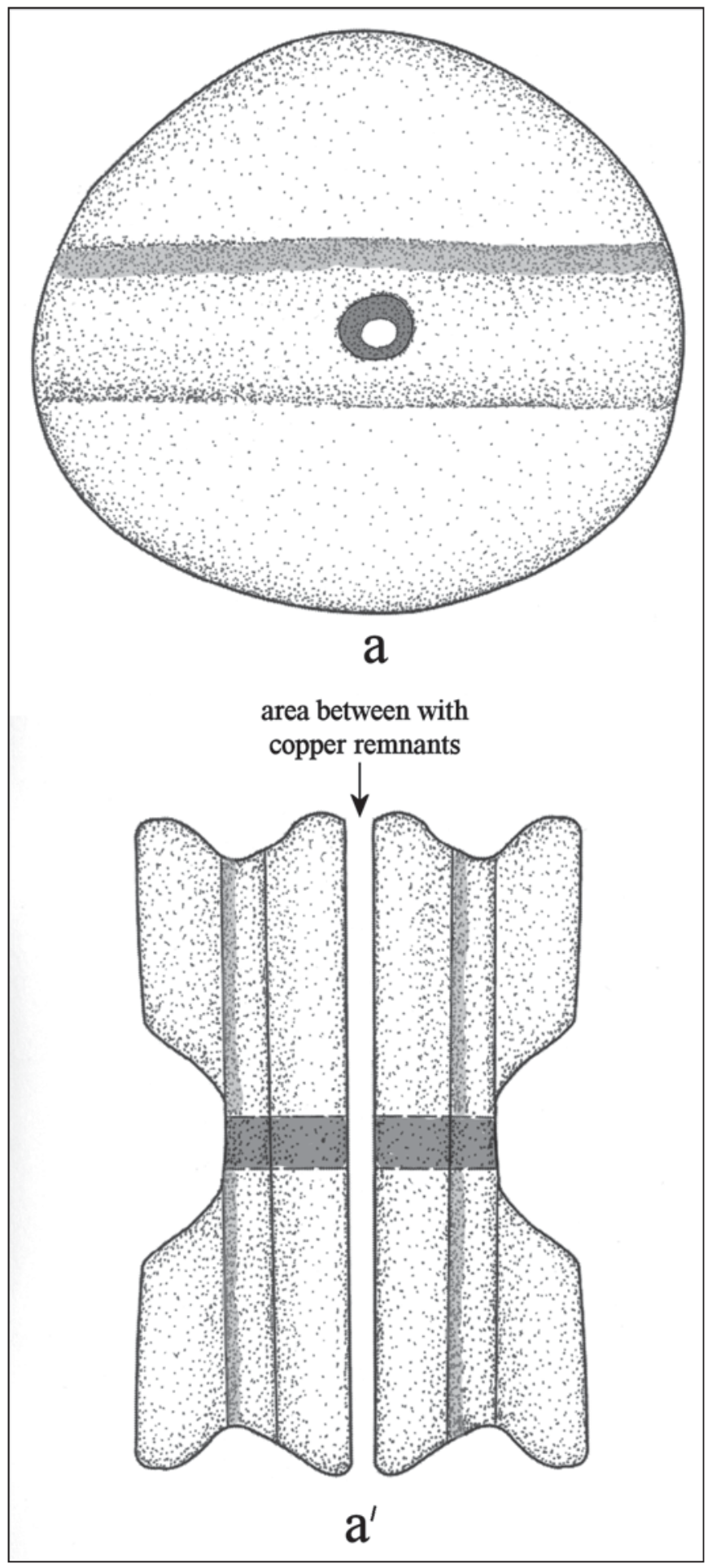

Figure 6. Hematite ear spools from 41SA13: a, top down view; a', side view of the two ear spools. Drawing based on Arnold (1940). 
variety of Belcher Ridged (var. Byram Ferry). During the span of time the two Caddo sites were occupied, the use of bone temper in vessel manufacture increased from 25 percent to 60 percent, and conversely the use of grog temper in vessel manufacture decreased from 75 percent (at 41SA13) to only 40 percent at $41 \mathrm{SA} 7$.

The use of burned animal bone for the temper of ceramic vessels is a distinctive characteristic of East Texas Caddo ceramic sherd assemblages: 25 percent of the sherds from 41SA13 have bone temper and 60 percent of the 41SA7 sherds are bone-tempered. Sherd assemblages with high proportions ( $>40$ percent of the sherd assemblage) of bone temper are concentrated in only a few locales across East Texas, most notably in the Toledo Bend Reservoir area along the middle Sabine River and in sites in the Angelina River basin (Perttula 2015:Figure 11). Late Caddo (ca. A.D. 1400-1680) sites and assemblages with high proportions of bone temper are found in several sites in the mid-Sabine and Angelina River basins, including 41SA7. In fact, these sites are part of a previously identified Late Caddo period bone-tempered and brushed ceramic tradition (Perttula et al. 2011b:Figure 6-71).

\section{ACKNOWLEDGMENTS}

I appreciate the assistance provided by Jonathan Jarvis at the Texas Archeological Research Laboratory

at The University of Texas at Austin in facilitating access to the records and collections from 41SA7 and 41SA13. Lance Trask prepared the figures for this article.

\section{REFERENCES CITED}

Arnold, G. E.

1940 Site forms for 41SA7 and 41SA13. On file, Texas Archeological Research Laboratory, The University of Texas at Austin.

Fields, R. C.

1995 Analysis of Native-Made Ceramics. In The Deshazo Site, Nacogdoches County. Texas, Volume 2: Artifacts of Native Manufacture, edited by D. A. Story, pp. 173-232. Studies in Archeology 21. Texas Archeological Research Laboratory The University of Texas at Austin.

Girard, J. S.

2007 Byram Ferry (16BO17): A Middle to Late Caddo Period Mound Site in the Red River Floodplain, Northwest Louisiana. Caddo Archeology Journal 16:9-25.

$\operatorname{Im}$, H. J.

1975 An Analysis of the G. E. Arnold Survey of East Texas. Master's thesis, Department of Anthropology, The University of Texas at Austin.

Jelks, E. B.

1965 The Archeology of McGee Bend Reservoir, Texas. Ph.D. dissertation, Department of Anthropology, The University of Texas at Austin.

Middlebrook, T.

2014 Early European Descriptions of Hasinai Elites and Understanding Prehistoric Caddo Mortuary Practices in Shelby County, Texas. Bulletin of the Texas Archeological Society 85:83-110.

Perttula, T. K.

2015 East Texas Caddo Ceramic Sherd Database. Journal of Northeast Texas Archaeology 51:1-46. 
Perttula, T. K., D. B. Kelley, and R. A. Ricklis (assemblers and editors)

2011 Archeological Investigations at the Lang Pasture Site (41AN38) in the Upper Neches River Basin of East Texas. Report No. 129. Texas Department of Transportation, Archeological Studies Program, Environmental Affairs Division, Austin.

Story, D. A. (editor)

1982 The Deshazo Site, Nacogdoches County, Texas, Vol. 1: The Site, Its Setting, Investigations, Cultural Features, Artifacts of Non-Native Manufacture, and Subsistence Remains. Texas Antiquities Permit Series No. 7. Texas Antiquities Committee, Austin.

1995 The Deshazo Site, Nacogdoches County, Texas, Vol. 2: Artifacts of Native Manufacture. Studies in Archeology 21. Texas Archeological Research Laboratory, The University of Texas at Austin.

Suhm, D. A. and E. B. Jelks (editors)

1962 Handbook of Texas Archeology: Type Descriptions. Special Publication No. 1, Texas Archeological Society, and Bulletin No. 4, Texas Memorial Museum, Austin. Reprinted in 2009, Gustav's Library, Davenport, Iowa. 